\title{
THE FRESHWATER COPEPOD GENUS Mesocyclops (Copepoda, Cyclopoida, Cyclopidae) IN VIETNAM
}

\author{
Tran Duc Luong*, Dang Ngoc Thanh, Ho Thanh Hai
}

Institute of Ecology and Biological Resources, VAST, Vietnam

Received 27 May 2020, accepted 27 September 2020

\begin{abstract}
The freshwater copepod Mesocyclops Sar, 1914, a species-rich genus within the family Cyclopidae Rafinesque, 1815, is common in tropical areas. In addition, the genus members are used for the biological control of mosquito larvae (Anopheles, Aedes) which are vectors for transmitting dengue fever. In Vietnam, a total of 11 Mesocyclops species have been recorded in inland freshwater bodies. Of which, one endemic species (M. sondoongensis Tran \& Hołyńska, 2015) and two species were described from Vietnam, namely M. yenae Hołyńska, 1998; $M$. ferjemurami Hołyńska \& Vu, 2000. Diagnostic characteristics, habitat, and distribution of all 11 species are provided. Additionally, a pictorial key to all Vietnamese Mesocyclops is presented.
\end{abstract}

Keywords: Cyclopidae, Mesocyclops, biodiversity, pictoral key, taxonomy, Vietnam.

Citation: Tran Duc Luong, Dang Ngoc Thanh, Ho Thanh Hai, 2020. The freshwater copepod genus Mesocyclops (Copepoda, Cyclopoida, Cyclopidae) in Vietnam. Academia Journal of Biology, 42(4): 1-16. https://doi.org/10.15625/2615-9023/v42n4.15310

*Corresponding author email: tranducluongiebr@gmail.com

C2020 Vietnam Academy of Science and Technology (VAST) 


\section{INTRODUCTION}

In the family Cyclopidae, the genus Mesocyclops Sar, 1914 is considered to be a cosmopolitan group, but more dominant in the tropics and more common in eutrophic water bodies. To date, 79 Mesocyclops species have been described (Hołyńska, 1997, 2000, 2006; Karanovic, 2006; Hołyńska and Stoch, 2012; Alekseev et al., 2013; Papa and Hołyńska, 2013; Tran and Hołyńska, 2015).

Many studies indicated that Mesocyclops species can kill larvae of Anopheles spp., Aedes spp. (Marten et al., 1989, 1994; Vu Sinh Nam et al., 1998). Thus, they are often used as biological control agents of mosquito larvae which is known as vectors for dengue transmission in Mexico, Brazil, Australia, India and Vietnam (Marten et al., 1989, 1994; Vu Sinh Nam et al., 1998, 2000, 2004).

In Vietnam, based on the species characteristics of the genus Mesocyclops as described by Sars (1914), Kiefer (1927) and Rylov (1948), Dang Ngoc Thanh (1977, 1980), Dang Ngoc Thanh et al. (1980, 2002) recorded only one species of Mesocyclops leuckarti (Claus, 1857) in inland freshwater bodies of Vietnam. However, Kiefer (1981) indicated that $M$. leuckarti was only distributed in the Palaearctic region including Europe, Russia, North China, South Korea and Japan, not extending to the tropic area. Compared to the diagnosis of $M$. leuckarti proposed by Kiefer (1981), the description and drawings by Dang Ngoc Thanh et al. $(1980,2002)$ has significant differences in antennule, caudal rami, thoracopod and especially seminal receptacles in females. These differences suggested that the presence of this species in Vietnam could be questionable.

Research on the genus Mesocyclops has been conducted in Vietnam on both taxonomic and applied aspects. In a joint project with the Central Institute of Hygiene and Epidemiology in Hanoi on the use of Mesocyclops in the biological control of Aedes (mosquitoes transmitting dengue fever) in Vietnam, Hołyńska (1997, 1998), and Hołyńska \& Vu (2000) recorded 9 species of the genus Mesocyclops in freshwater of Vietnam, including: Mesocyclops affinis Van de Velde, 1987; M. aspericornis (Daday, 1906); M. feriemurami Hołyńska \& Vu, 2000; M. ogunnus Onabamiro, 1957; M. pehpeiensis $\mathrm{Hu}, 1943 ; M$. shenzhenensis Guo, 2000; M. thermocyclopoides Harada, 1931; M. yenae Hołyńska, 1998 and $M$. woutersi Van de Velde, 1987. Of which, two were described as new to science: M. yenae Hołyńska, 1998 from Hai Phong City and M. feriemurami Hołyńska \& Vu, 2000 from Khanh Hoa Province. Hołyńska (1997, 1998, 2000) used the system of diagnostic features of the genus Mesocyclops of Van de Velde (1984) which was verified and now widely accepted in the world. Recently, Tran \& Hołyńska (2015) described $M$. sondoongensis from the Son Doong cave, Quang Binh Province.

In studies following the diagnostics of the genus Mesocyclops proposed by Dang Ngoc Thanh et al., 1980, most specimens collected in Vietnam were identified as $M$. leuckarti (Claus, 1857) or Mesocyclops spp. (Hoang Dinh Trung \& Phan Doan Dang, 2011; Vo Van Phu \& Hoang Dinh Trung, 2012; Phan Doan Dang et al., 2015; Le Thi Nguyet Nga \& Phan Doan Dang, 2013, 2015a,b, 2019). This resulted in the confusion and misunderstanding of the zooplankton biodiversity of Vietnam, and could caused mistakes in selecting biological control agents.

The paper aims to provide an updated review and identification key of the genus Mesocyclops in Vietnam, which will also facilitate further research on freshwater copepods of Vietnam.

\section{MATERIALS AND METHODS}

Freshwater copepod specimens were collected from various localities in Vietnam during the period of 2005-2019, using a 100 $\mu \mathrm{m}$ mesh-sized plankton net. Samples were fixed and stored in 70\% ethanol and deposited in the Department of Aquatic Ecology, Institute of Ecology and Biological Resources (IEBR), Ha Noi, Vietnam. The specimens were observed with a differential interference contrast microscope (Nikon Eclipse Ni-U). 
Illustrations were made with the aid of a camera lucida attached to the microscope. The following abbreviations are used, where required, throughout the text and figures: Endp = endopod; Exp = exopod; P1-P5 = swimming legs $1-5$.

\section{RESULTS AND DISCUSSION}

Species composition
A total of 11 Mesocylops species are recognized from inland freshwater bodies of Vietnam (Table 1). Of which, one species is considered to be endemic to Vietnam, $M$. sondoongensis Tran \& Hołyńska, 2015 and two species (M. yenae Hołyńska, 1998, M. feriemurami Hołyńska \& Vu, 2000) were described for the first time from Vietnam's copepod fauna.

Table 1. List of species and distribution of the genus Mesocyclops in Vietnam

\begin{tabular}{|c|l|c|c|c|c|c|c|c|c|}
\hline \multirow{2}{*}{ STT } & \multirow{2}{*}{ Taxon } & \multicolumn{6}{|c|}{ Geographic distribution inVietnam } \\
\cline { 4 - 9 } & & I & II & III & IV & V & VI & VII \\
\hline 1 & Mesocyclops affinis Van de Velde, 1987 & + & + & + & & + & + & + \\
\hline 2 & Mesocyclops aspericornis (Daday, 1906) & + & + & + & + & + & + & + \\
\hline 3 & Mesocyclops augusti Papa \& Hołyńska, 2013 & + & & & & & & \\
\hline 4 & Mesocyclops dissimilis Defaye \& Kawabata, 1993 & + & + & + & & & & \\
\hline 5 & Mesocyclops ferjemurami Hołyńska \& Vu, 2000 & & & & & & + & \\
\hline 6 & Mesocyclops ogunnus Onabamiro, 1957 & + & & + & & & + & + \\
\hline 7 & Mesocyclops pehpeiensis Hu, 1943 & + & + & + & + & + & + & + \\
\hline 8 & Mesocyclops sondoongensis Tran \& Hołyńska, 2015* & & & & + & & & \\
\hline 9 & Mesocyclops thermocyclopoides Harada, 1931 & + & + & + & & & + & + \\
\hline 10 & Mesocyclops woutersi Van de Velde, 1987 & + & + & + & + & + & + & + \\
\hline 11 & Mesocyclops yenae Hołyńska, 1998 & + & & + & & & & \\
\hline
\end{tabular}

Abbreviations: I. Northeast region; II. Northwest region; III. Red River delta and North Central coast regions; IV. North Central mountains region; V. Central highlands region; VI. South Central coast; VII. Mekong River delta; * Species endemic in Vietnam.

\section{Taxonomic part}

Order Cyclopoida Burmeister, 1834

Family Cyclopidae Rafinesque, 1815

Subfamily Cyclopinae Rafinesque, 1815

Genus Mesocyclops Sars, 1914

Typ species: Cyclops leuckarti Claus, 1857

Synonyms: Cyclops (Mesocyclops) Gurney, 1933: 286-287; Mesocyclops (Mesocyclops) Rylov, 1948: 292-293.

Diagnosis: Medium size Cyclopidae, cephalothorax oval or slightly elongated. Genital double-somite trapezoidal, slightly shrunk back. Seminal receptacle "T"-shaped, distal part dilated and almost sac-like. Caudal ramus cylindrical with two rami often parallel. Antennule 17-segmented, last segment ornamented with serrate hyaline membrane, with or without large notch. P1-P4 with 3- segmented rami. P1 basipodite with or without medial spine. P5 2-segmented, terminal segment with apical long seta and long inner spine.

In Vietnam, 11 species of this genus are currently known to be present.

\section{Mesocyclops affinis Van de Velde, 1987}

Mesocyclops affinis Van de Velde, 1987: 151-156, figs 15-27; Hołyńska, 200: 400405, figs 25-27.

Mesocyclops thermocyclopoides acutus Dussart \& Fernando, 1988: 254-255, figs 4350; Red \& Kay, 1992: 340-341, figs 4a-d. Synonymized by Hołyńska (1994).

Mesocyclops thermocyclopoides-Dussart \& Fernando, 1988 [partim]: 245-246, figs 8-10.

Type locality: A bomb hole, Madang Province, Papua New Guinea (Van de Velde, 1987). 
Diagnosis: Serrate hyaline membrane on last antennulary segment extending far beyond implantation of medial seta of segment, with one large notch. Caudal spinule pattern of antennary basipodite with an oblique row of tiny spinules starting at distal third of medial rim, group of short spinules near implantation of medial setae, group of relatively large spinules at laterodistal angle, spinules in longitudinal row near lateral margin and a row of oblique spinules next to long lateral spinules near base. Frontal surface of maxillary coxopodite bearing a distinct row of spinules. P1 basipodite lacking medial spine; medial expansion of basipodite of P1P4 with apical hairs; distal margin of P4 coupler with two small obtuse or acute outgrowths. Pediger 5 with only soft pilose laterally. Genital double-somite without hairs. Lateral arms of seminal receptacle wide and short; transverse ducts directed to each other at straight or nearly straight angle (not Vshaped) before connection with copulatory duct; copulatory duct straight or slightly curved. Caudal rami without medial hairs; spinules at implantation of lateral caudal setae present or absent and at implantation of lateralmost terminal setae always present; medialmost terminal seta about 2.5-3.5 times as long as lateralmost terminal seta.

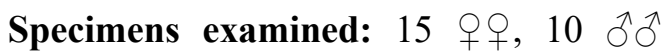
(IEBR-MESO-09-04), Sai Gon river, Ho Chi Minh City, VI. 2009, Tran D.L. leg.; 10 우, 6 $\widehat{\jmath}$ (IEBR-MESO-11-01), a fish pond, Quang Nam Province, VII. 2011, Tran D.L. leg.; 20 우, 25 ๙ึð (IEBR-MESO-12-05), Cau river, Thai Nguyen Province, VIII. 2012, Tran D.L. leg.; 5 우, 1 ㅇ (IEBR-MESO-15-10), Nhue river, Ha Nam Province, X. 2015, Nguyen T.C. leg.; 14 우, 5 ठึ ${ }^{\lambda}$ (IEBR-MESO-1901), Krong Kmar reservoir, Dak Lak Province, III. 2019, Dang V.D. leg.

Ecology: This species has been found in aquaculture ponds, reservoirs, lakes and rivers.

Records from Vietnam: Lai Chau, $\mathrm{Ha}$ Giang, Thai Nguyen, Phu Tho, Ha Nam, Nghe An, Quang Nam, Ninh Thuan, Dak Lak, Ho Chi Minh City, Kien Giang (this study), Bac
Giang, Phu Tho, Hung Yen, Hai Phong, Nam Dinh, Ha Noi, Nghe An, Ha Tinh, Thua Thien-Hue, Da Nang, Khanh Hoa, Ho Chi Minh City, Dong Nai (Vu et al., 2000).

Distribution: Papua New Guinea (Van de Velde, 1987), Indonesia, Malaysia (Hołyńska, 2000).

\section{Mesocyclops aspericornis (Daday, 1906)}

Cyclops aspericornis Daday, 1906: 181184, Pl. 14, figs 1-6.

Mesocyclops aspericornis-Kiefer, 1981: 172-173, Pl. 10; Van de Velde, 1984: 42-45, figs 28-29; Lim \& Fernando, 1985: 83, figs 54-56; Hołyńska, 2000: 392-398, figs 20-23; Gutiérrez-Aguirre et al., 2003: 1349-1361, figs $1-6$.

Mesocyclops leuckarti-Kiefer, 1938: 60, figs 27-29.

Mesocyclops iranicus Lindberg, 1936: $12-$ 16 , figs $17-21$. Synonymized by Ghenne \& Fiers (2000).

Type locality: Bogor, Indonesia (Daday, 1906).

Diagnosis: Serrate hyaline membrane on last antennulary segment extending far beyond implantation of medial seta of segment, with one large notch at $1 / 3$ distal part. Caudal spinule ornamentation of antennary basipodite with an oblique row of small spines starting at distal third of inner margin, group of tiny spinules near implantation of medial setae, and a group of small spinules between proximal oblique and longitudinal spinule rows. Frontal surface of maxillary coxopodite bearing a distinct row of hair-like spinules. P1 basipodite without medial spine; medial expansion of basipodite of P1-P4 with apical hairs; distal margin of P4 coupler bearing two small, triangular outgrowths. Pediger 5 with soft hairs laterally. Genital double-somite without hairs. Lateral arms of seminal receptacle wide and elongate; transverse ducts directed to each other at acute angle (V-shaped) before connection with copulatory duct; copulatory duct slightly curved. Caudal rami with medial hairs; spinules at implantation of lateral caudal and 
lateralmost terminal setae present; medialmost terminal seta about 1.2-1.4 times as long as lateralmost terminal seta.

Specimens examined: $10 \hat{\partial} \widehat{\partial}, 30$ 우 (IEBR-MESO-09-02), Cau river, Thai Nguyen Province, IV. 2009, Tran D.L. leg.; 5 우 (IEBR-MESO-09-03), Nhue river, Ha Nam Province, IV. 2009, Tran D.L. leg.; 20

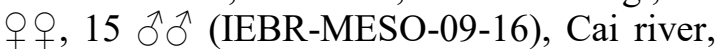
Kien Giang Province, XII. 2009, Tran D.L. leg.; $10 \widehat{\widehat{\partial}} \widehat{\text {, }, 10}$ 웅 (IEBR-MESO-18-07), Tram Chim National Park, Dong Thap Province, IX. 2018, Tran D.L. leg.

Ecology: This species has been found in various freshwaters bodies, such as aquaculture ponds, reservoirs, lakes and rivers, and especially favors the stagnant and eutrophic waters.

\section{Records from Vietnam: Widely distributed.}

Distribution: Thailand, Malaysia (Lim \& Fernando, 1985), Indonesia (Daday, 1906; Dussart \& Fernando, 1985), Philippines (Van de Velde, 1987; Hołyńska, 2000), Papua New Guinea (Van de Velde, 1987), Australia (Brown et al.,1991; Hołyńska \& Brown, 2003), Ethiopia, Ghana, Nigeria (Van de Velde, 1984), Mexico, Colombia (GutiérrezAguirre et al., 2003, 2006).

\section{Mesocyclops augusti Papa \& Hołyńska, 2013}

Mesocyclops augusti Papa \& Hołyńska, 2013: 290-312; figs 2-6.

Type locality: Siloton lake, Mindanao, Philippines (Papa \& Hołyńska, 2013).

Diagnosis: Serrate hyaline membrane on last antennulary segment extending far beyond implantation of medial seta of segment, with one large notch. Caudal spinule ornamentation of antennary basipodite with an oblique row of tiny spinules starting at distal third of inner margin, group of medium sized spinules near implantation of medial setae, spinules in longitudinal row near lateral margin and a row of oblique spinules next to long lateral spinules near base. Row of spinules present on frontal surface of maxillary coxopodite. P1 basipodite lacking medial spine; medial expansion of basipodite of P1-P4 with apical hairs; outgrowths small and acute on distal margin of P4 coupler. Pediger 5 pilose laterally, naked dorsally. Genital double-somite without hairs. Lateral arms of seminal receptacle wide and short; transverse ducts directed to each other at obtuse angle (not V-shaped) before connection with copulatory duct; copulatory duct strongly curved. Hindgut on anal operculum with oblique field of short spinules, and 1-1 row of long spinules near anterior margin of caudal rami. Caudal rami without medial hairs; spinules at implantation of lateral caudal and lateralmost terminal setae present; medialmost terminal seta about 2.62.8 times as long as lateralmost terminal seta.

Specimens examined: 5 우 (IEBRMESO-17-06), Xa Huong lake, Tam Dao, Vinh Phuc Province, X. 2017, Nguyen T.C. leg.

Ecology: This species is found only in large freshwater bodies like lakes and reservoirs.

Records from Vietnam: Vinh Phuc (this study, Papa \& Hołyńska, 2013).

Distribution: Philippines (Mindanao) (Papa \& Hołyńska, 2013).

\section{Mesocyclops dissimilis Defaye \& Kawabata, 1993}

Mesocyclops dissimilis Defaye \& Kawabata, 1993: 121-126, figs 1-25; Ueda, Ishida \& Imai, 1997: 64-66, figs 22-37.

Type locality: Biwa lake, Japan (Defaye \& Kawabata, 1993).

Diagnosis: Serrate hyaline membrane on last antennulary segment extending far beyond implantation of medial seta of segment, with two large notches at distal third of segment. Caudal spinule pattern of antennary basipodite with an oblique row of tiny spinules starting at distal third of inner margin, group of small spinules near implantation of medial setae, large spinules in longitudinal row near lateral margin and a row of oblique spinules next to long lateral 
spinules near base. Row of spinules present on frontal surface of maxillary coxopodite. P1 basipodite lacking medial spine; medial expansion of basipodite of P1-P4 with apical hairs; outgrowths small and acute on distal margin of P4 coupler. Pediger 5 with lateral hairs only. Genital double-somite without hairs. Seminal receptacle with wide and short lateral arms; transverse ducts directed to each other at acute angle (V-shaped) before connection with copulatory duct; copulatory duct strongly curved. Caudal rami without medial hairs; spinules at implantation of lateral caudal and lateralmost terminal setae present; medialmost terminal seta about 2.72.9 times as long as lateralmost terminal seta.

Specimens examined: 25 우, 15 $\widehat{\overbrace{}}$ (IEBR-MESO-08-06), Pa Khoang lake, Dien Bien Province, VI. 2008, Tran D.L. leg.; 50 우오, 50 Љぇ (IEBR-MESO-12-02), Bat Chat lake, Lai Chau Province, V. 2012, Tran D.L. leg.; 6 우, 6 ภํ (IEBR-MESO-13-16), Cau river, Bac Giang, IV, 2013, Nguyen D.T. leg.

Ecology: Aquaculture ponds, lakes and river deltas, hilly and mountainous areas.

Records from Vietnam: Dien Bien, Lai Chau, Thai Nguyen, Hai Duong, Vinh Phuc (this study); Vinh Phu? (Vu et al., 2000).

Distribution: Japan, China (Defaye \& Kawabata, 1993; Guo, 2000).

Mesocyclops ferjemurami Hołyńska \& Vu, 2000

Mesocyclops ferjemurami Hołyńska \& $\mathrm{Vu}, 2000$ : 197-206, figs 1-4.

Type locality: Nha Trang, Khanh Hoa Province, Vietnam (Hołyńska \& Vu, 2000).

Diagnosis: Serrate hyaline membrane on last antennulary segment extending far beyond implantation of medial seta of segment, with one large notch at distal third of segment. Caudal spinule pattern of antennary basipodite with an oblique row of tiny spinules starting at distal third of inner margin, group of small spinules near implantation of medial setae, a triangular group of spinules between the spinule group at height of medial setae and oblique row of tiny spinules starting at distal half of medial rim, large spinules in longitudinal row near lateral margin and a row of oblique spinules next to long lateral spinules near base. Frontal surface of maxillary coxopodite without spinule ornamentation. P1 basipodite lacking medial spine; medial expansion of basipodite of P1-P4 with apical hairs; distal margin of P4 coupler with two large acute outgrowths. Pediger 5 and genital double-somite without hairs. Lateral arms of seminal receptacle elongated, transverse ducts meet at deep acute angle anterior to copulatory pore (V-shaped), copulatory duct slightly to strongly curved. Caudal rami without medial hairs; spinules at implantation of lateral caudal and lateralmost terminal setae present; medialmost terminal seta about 3.0 times as long as lateralmost terminal seta.

Specimens examined: 6 우 (IEBRMESO-11-02), Tra Khuc river, Quang Ngai Province, VII. 2011, Tran D.L. leg.; 37 o 9 , 12 ऽิ (IEBR-MESO-18-03), a reservoir in $\mathrm{Cu}$ Lao Cham Island, Quảng Nam Province, III. 2018, Tran D.L. leg.

Ecology: Mainly inhabiting fish ponds and rivers in delta areas.

Records from Vietnam: Quang Nam, Quang Ngai (this study); Khanh Hoa (Hołyńska \& Vu, 2000).

Distribution: Thailand (Alekseev \& Sanoamuang, 2006).

\section{Mesocyclops ogunnus Onabamiro, 1957}

Mesocyclops ogunnus Onabamiro, 1957: 125-127, figs 7-12; Van de Velde, 1984: 3136, figs 19-22; Dussart \& Fernando, 1988: 250-251, figs 27-30; Reid \& Kay, 1992: 338339, figs 3d-f; Mirabdullayev, 1996: 96, figs 12-17; Hołyńska, 1997: 27-30, fig. 4g; Hołyńska, 2000: 398-400, figs 24a-f.

Type locality: Ogun river, Abeokuta, Nigeria (Onabamiro, 1957).

Diagnosis: Serrate hyaline membrane on last antennulary segment extending far beyond implantation of medial seta of segment, with one large notch. Caudal spinule pattern of antennary basipodite with an 
oblique row of fine spinules starting at distal third of inner margin, row of large spinules near implantation of medial setae, spinules in longitudinal row near lateral margin, a row of oblique spinules next to long lateral spinules near base. Maxillulary palp bearing a row of large spinules. Frontal surface of maxillary coxopodite bearing distinct a row of spinules. P1 basipodite without medial spine; medial expansion of basipodite of $\mathrm{P} 1-\mathrm{P} 4$ with apical hairs; distal margin of $\mathrm{P} 4$ coupler with two small obtuse or acute outgrowths. Pediger 5 pilose laterally and dorsally. Genital doublesomite without hairs. Lateral arms of seminal receptacle wide and short; transverse ducts directed to each other at obtuse angle (not Vshaped) before connection with copulatory duct; copulatory duct strongly curved. Caudal rami without medial hairs; spinules at implantation of lateral caudal setae present or absent and at implantation of lateralmost terminal setae always present; medialmost terminal seta about 2.6-2.8 times as long as lateralmost terminal seta.

Specimens examined: 10 웅, 5 तิ $\widehat{O}$ (IEBR-MESO-12-01), Nhue river, Ha Nam, IV. 2012, Tran D.L. leg.; 8 우 (IEBRMESO-14-07), Han river, Da Nang City, VIII. 2014, Tran D.L. leg.

Ecology: It lives in lakes, ponds and river deltas and hilly areas.

Records from Vietnam: Quang Ninh, Vinh Phuc, Ha Nam, Nghe An, Khanh Hoa, Dong Nai, Kien Giang (this study); Lang Son, Bac Giang, Hai Phong, Nam Dinh, Thua Thien-Hue, Da Dang, Khanh Hoa, Ninh Thuan, Ca Mau (Vu et al., 2000).

Distribution: Nigeria (Onabamiro, 1957; Van de Velde, 1984), Senegal, Mali, Mozambique, Ethiopia, Kenya (Van de Velde, 1984), Brazil (Reid and Pinto-Coelho, 1994), Uzbekistan (Mirabdullayev, 1996), China (Guo, 2000), Malaysia (Hołyńska, 2000), Papua New Guinea (Hołyńska, 2000), Thailand (Alekseev \& Sanoamuang, 2006).

\section{Mesocyclops pehpeiensis Hu, 1943}

Mesocyclops leuckrti pehpeiensis $\mathrm{Hu}$, 1943: 124-126, figs 2-4.
Mesocyclops pehpeiensis-Shen, 1956: 9, pl. 3, figs 26-29; Tai \& Chen, 1979: 409-410, figs 247-248; Kawabata \& Defaye, 1994: 151-153, figs 6-7; Guo, 2000: 34-35, figs 2-4.

Mesocyclops ruttneri Kiefer, 1981:178180, fig. 14 (synonymyzed by Guo, 2000); Reid, 1993: 177-1983, figs 3-5; Mirabdullayev, 1996: 98-99, figs 23-26; Ueda, Ishida \& Imai, 1997: 66-68, figs 38-50.

Type locality: Pehpei, Chongqing, China (Hu, 1943; Guo, 2000).

Diagnosis: Serrate hyaline membrane on last antennulary segment extending far beyond implantation of medial seta of segment, with one large notch. Caudal spinule ornamentation of antennary basipodite with an oblique row of tiny spinules starting at distal third of inner margin, a row of medium sized spinules near implantation of medial setae, large spinules in a longitudinal row near lateral margin and a row of oblique spinules next to long lateral spinules near base. Row of spinules present on frontal surface of maxillary coxopodite. P1 basipodite without medial spine; medial expansion of basipodite of P1-P3 with apical hairs, medial expansion of $\mathrm{P} 4$ basis naked; distal margin of $\mathrm{P} 4$ coupler with two large acute outgrowths. Pediger 5 and genital double-somite without hairs laterally and dorsally. Lateral arms of seminal receptacle short, transverse ducts meet at deep acute angle anterior to copulatory pore (Vshaped), copulatory duct strongly curved. Caudal rami without medial hairs; spinules at implantation of lateral caudal and lateralmost terminal setae present; medialmost terminal seta about 3.0 times as long as lateralmost terminal seta.

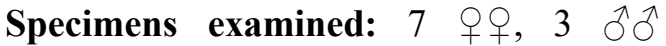
(IEBR-MESO-06-11), Huong river, Thua Thien-Hue, VI. 2006, Tran D.L. leg.; 30 우,

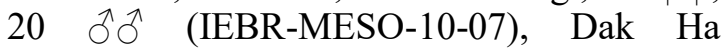
reservoir, Kon Tum Province, VI, 2010, Tran D.L. leg.; 12 우, 2 ๙ิठึ (IEBR-MESO-1208), Boi river, Hoa Binh Province, VII. 2012,

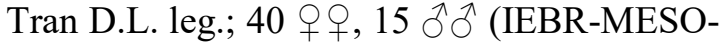
12-09), a fish pond, Viet Tri, Phu Tho, IX.

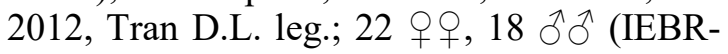


MESO-18-08), Tram Chim National Park, Dong Thap Province, IX. 2018, Tran D.L.

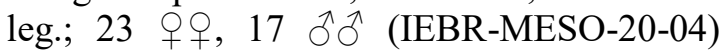
Vinh Cuu, Dong Nai Province, V.2020.

Ecology: It lives in lakes, ponds and river deltas and hilly areas.

Records from Vietnam: All provinces.

Distribution: Malaysia, Indonesia, Sri Lanka (Dussart \& Fernando, 1985, 1988), India (Hołyńska et al., 2003), China (Hu, 1943; Tai \& Chen, 1979; Guo, 2000), Japan (Kawabata and Defaye, 1994; Ueda, Ishida \& Imai, 1997), Kazakhstan, Uzbekistan (Mirabdullayev et al., 1995; Mirabdullayev, 1996), Mexico (Suárez-Morales et al., 2005), Cuba (Menéndez Diaz et al., 2006), Thailand (Alekseev \& Sanoamuang, 2006), USA (Reid, 1993; Connolly et al., 2019).

\section{Mesocyclops sondoongensis Tran \& Hołyńska 2015}

Mesocyclops sondongensis Tran \& Hołyńska, 2015: 661-686, figs 2-56.

Type locality: Son Doong cave, Phong Nha-Ke Bang National Park, Quang Binh, Vietnam (Tran \& Hołyńska, 2015).

Diagnosis: Serrate hyaline membrane of the last antennulary segment proximally extending to implantation of medial seta, without notch. Caudal surface ornamentation of antennal coxobasis with spinules in a longitudinal row along lateral margin not reaching height of insertion of exopodal seta; long curved row present, starting next to implantation of more proximal medial seta. Group of spinules present next to implantation of exopodite seta on frontal surface of antennal coxobasis. No spinules on frontal surface of maxillary coxopodite. P1 basipodite with medial spine; medial expansion of basipodite of $\mathrm{P} 1-\mathrm{P} 3$ with apical hairs, medial expansion of $\mathrm{P} 4$ basis naked; distal margin of P4 coupler with two small triangular-shaped outgrowths. Pediger 5 and genital doublesomite without hairs laterally and dorsally. Seminal receptacle with narrow lateral arms, transverse ducts directed to each other at obtuse angle next to copulatory pore (not V- shaped), copulatory duct short and slightly curved. Caudal rami without medial hairs; spinules at implantation of lateral caudal and lateralmost terminal setae present; medialmost terminal seta about 2.7 times as long as lateralmost terminal seta.

Specimens examined: 1 q (holotype, IEBR-COP3410), 1 त (allotype, IEBRCOP3411), 3 우 (paratypes, IEBR-

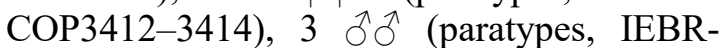
COP3415-3417) and 25 우, 13 ऊోఓ (IEBRCOP-AED04.13.025), Son Doong cave, Quang Binh Province, IV. 2013; Tran D. L. leg.; 46 우, 28 ऊิ수 (IEBR-COPAED04.13.026), Va cave, Quang Binh Province, IV. 2014, Tran D. L. leg.

Ecology: Living in underground water bodies in cave.

Records from Vietnam: Quang Binh (Son Doong cave, Va cave, Phong Nha-Ke Bang National Park, Quang Binh).

Distribution: Only known from Vietnam.

\section{Mesocyclops thermocyclopoides Harada, 1931}

Mesocyclops thermocyclopoides Harada, 1931: 161-162, figs 23-25; Kiefer, 1981: 153, 162-165, fig. 2, fig. 5; Van de Velde, 1987: 156, figs 28-30; Hołyńska, 1994: 100-109, figs 1-5; Ueda \& Ishida, 1997: 46-48, figs 45; Hołyńska, 2000: 431-436, figs 47a-e, figs 48a-d, fig. 49a; Gutiérrez-Aguirre et al., 2003: 352-363, figs $1-6$.

Mesocyclops cf. thermocyclopoides-Dahm \& Fernando, 1993: 9-18, figs 5-6.

Mesocyclops thermocyclopoides acutus Dussart \& Fernando, 1988: 254, figs 43-50; Reid \& Kay, 1992: 340-341, fig. 4.

Type locality: Candidius lake, Taiwan (Harada, 1931).

Diagnosis: Serrate hyaline membrane on last antennulary segment extending far beyond implantation of medial seta of segment, with one large notch. Caudal spinule ornamentation of antennary basipodite with an oblique row of tiny spinules starting at distal half of medial rim, a row of large spinules 
near implantation of medial setae, large spinules in longitudinal row near lateral margin, a row of oblique spinules next to long lateral spinules near base. Frontal surface of maxillary coxopodite bearing a distinct row of spinules. P1 basipodite without medial spine; medial expansion of basipodite of $\mathrm{P} 1-\mathrm{P} 4$ with apical hairs; outgrowths of $\mathrm{P} 4$ coupler small, obtuse. Pediger 5 with dorsal and lateral soft hairs. Genital double-somite with dorsal hairs in anterior half. Seminal receptacle with lateral arms wide and short; transverse ducts directed to each other at straight or nearly straight angle (not V-shaped) before connection with copulatory duct; copulatory duct varies from slightly to strongly curved. Caudal rami without medial hairs; spinules at implantation of lateral caudal and lateralmost terminal setae absent; medialmost terminal seta about 3.0 times as long as lateralmost terminal seta.

Specimens examined: 13 우, 5 ถึત (IEBR-MESO-08-11) temporary pond, Ninh Tru, Ninh Thuan, XI. 2008, Nguyen D.T. leg.; 50 우오, 50 ㅎํ (IEBR-MESO-11-03), West lake, Ha Noi, VII. 2011, Tran D.L. leg.; 15 오오, 5 $\widehat{\jmath}$ (IEBR-MESO-13-19), Cau river, Thai Nguyen Province, IV. 2013, Nguyen D.T. leg.

Ecology: Wide variety of habitats, such as aquaculture ponds, reservoirs, lakes and rivers.

Records from Vietnam: Dien Bien, Phu Tho, Thai Nguyen, Quang Ninh, Ha Noi, Nghe An, Da Nang, Ninh Thuan, Can Tho (this study); Lang Son, Quang Ninh, Bac Ninh, Bac Giang, Hung Yen, Phu Tho, Ha Noi, Nam Dinh, Ha Tinh, Da Nang, Ninh Thuan, Khanh Hoa, Dong Nai, Can Tho, Kien Giang (Vu et al., 2000).

Distribution: Taiwan (Harada, 1931), Myanmar, Malaysia, Indonesia (Hołyńska, 1994, 2000); Japan (Ueda \& Ishida, 1997), Thailand (Sanoamuang, 2002); China (Guo, 2000), Mexico (Gutiérrez-Aguirre et al., 2003).

\section{Mesocyclops woutersi Van de Velde, 1987}

Mesocyclops woutersi Van de Velde, 1987: 156-157, figs 31-44; Hołyńska, 2000: 414-418, figs 35-37.
Mesocyclops guangxiensis Reid \& Kay, 1992: 332-338, figs 1-2 (Synonymized by Hołyńska, 1997).

Type locality: Coral gravel-pit, Madang Province, Papua New Guinea (Van de Velde, 1987).

Diagnosis: Serrate hyaline membrane on last antennulary segment extending far beyond implantation of medial seta of segment, with one large notch. Caudal spinule pattern of antennary basipodite with an oblique row of tiny spinules starting at distal third of inner margin, group of short spinules near implantation of medial setae, large spinules in longitudinal row near lateral margin and a row of oblique spinules next to long lateral spinules near base. Frontal surface of maxillary coxopodite bearing distinct a row of spinules. P1 basipodite lacking medial spine; medial expansion of basipodite of P1P4 with apical hairs; distal margin of P4 coupler with two small obtuse or acute outgrowths. Pediger 5 with lateral hairs only. Genital double-somite without hairs. Seminal receptacle with wide and short lateral arms; transverse ducts directed to each other at acute angle (V-shaped) before connection with copulatory duct; copulatory duct strongly curved. Caudal rami without medial hairs; spinules at implantation of lateral caudal and lateralmost terminal setae absent; medialmost terminal seta about 3.0 times as long as lateralmost terminal seta.

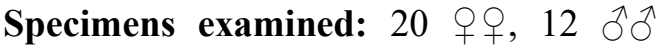
(IEBR-MESO-09-05), Nui Coc reservoir, Thai Nguyen Province, VI. 2009, Tran D.L. leg.; 20 우우, 20 ठึठ (IEBR-MESO-12-13), Bien Ho lake, Gia Lai Province, X. 2012, Tran D.L. leg.; 50 오, 30 $\widehat{\jmath}$ (IEBR-MESO14-03), Son river, Quang Binh Province, IV.

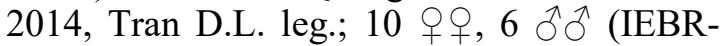
MESO-16-06), ricefield, Tu Ki, Hai Duong Province, X. 2016, Dang V.D. leg.; 20 우, 7

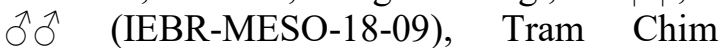
National Park, Dong Thap Province, IX. 2018, Tran D.L. leg.

Ecology: This species has been found in various freshwaters bodies, such as 
aquaculture ponds, reservoirs, lakes and rivers, and especially favors the stagnant and eutrophic waters.

Records from Vietnam: All provinces.

Distribution: Papua New Guinea (Van de Velde, 1987; Hołyńska, 2000), Laos (Reid \& Kay, 1992), China (Guo, 2000), Japan, Australia (Hołyńska \& Brown, 2003).

\section{Mesocyclops yenae Hołyńska, 1998}

Mesocyclops yenae Hołyńska, 1998: 337 347, figs 1-26.

Mesocyclops cf. yenae Hołyńska, 2000: 382-385, figs $14-15$, figs $49 \mathrm{~b}-\mathrm{c}$.

Type locality: Thua Thien-Hue, Viet Nam (Hołyńska, 1998).

Diagnosis: Serrate hyaline membrane on last antennulary segment extending beyond implantation of medial seta of segment, with one large notch. Caudal spinule pattern of antennary basipodite with large spinules in longitudinal row near lateral margin and a row of oblique spinules next to long lateral spinules near base; lacking oblique row of tiny spinules starting at distal third of inner margin. No spinules on frontal surface of maxillary coxopodite. P1 basipodite without medial spine; medial expansion of basipodite of P1-P3 with apical hairs, medial expansion of $\mathrm{P} 4$ basis naked; distal margin of $\mathrm{P} 4$ coupler with two large acute outgrowths. Pediger 5 and genital double-somite without hairs laterally and dorsally. Lateral arms of seminal receptacle elongated and curved backward; transverse ducts directed to each other at straight or nearly straight angle (not Vshaped) before connection with copulatory duct; copulatory duct straight. Caudal rami without medial hairs; spinules at implantation of lateral caudal and lateralmost terminal setae present; medialmost terminal seta about 3.54.0 times as long as lateralmost terminal seta.

Specimens examined: 6 q 9,2 수 (IEBR-MESO-16-09), Truoi lake, Thua Thien-Hue, X. 2016, Tran D.L. leg.; 3 q 9 , 1 đô (IEBR-MESO-11-02) a fish pond Duy Xuyen, Quang Nam Province, VII, 2011, Tran D.L. leg.; 4 우우 (IEBR-MESO-17-02), temporary pond, Thuy Nguyen, Hai Phong Province, III, 2017, Dang V.D. leg.

Ecology: Mainly inhabiting aquaculture pond, lake and river in delta area.

Records from Vietnam: Hai Phong, Thua Thien-Hue, Quang Nam (this study); Thua Thien-Hue (Hołyńska, 1998); Thua Thien-Hue, Hai Phong (Vu et al., 2000).

Distribution: Papua New Guinea (Hołyńska, 2000).

\section{DISCUSSION}

Previously, Dang Ngoc Thanh (1980), and Dang Ngoc Thanh et al. (1980, 2002) recorded only Mesocyclops leuckarti (Claus, 1857) in inland freshwater bodies of Vietnam. However, only Dang Ngoc Thanh et al. (1980) provided the description of this species based on Vietnamese specimens. Accordingly, $M$. leuckarti in Vietnam was recognized as: antennule with a comb-shaped hyaline plate, with a deep notch at $1 / 3$ of distal part; caudal rami nearly parallel, length 3.0-3.5 times width, outer margin smooth; medialmost terminal seta of caudal ramus not exceeding half of the inner terminal seta; seminal receptacle T-shaped, distal part large, sac-like; lateral arms wide and straight; anterior margin of proximal part concave in the middle; P4 Endp-3 elongated, two apical spines approximately same length; intercoxal plate with two small process-like knobs; P5 2segmented, distal segment with a long apical seta and a medial spine, apical seta 2.0 times as long as medial spine.

In the description of Dang Ngoc Thanh et al. (1980), there were some comments as follows: 1) "Intercoxal plate of P4 with two small process-like knobs, with small spine in tip" however, in M. leuckarti, intercoxal plate of P4 with two large acute outgrowths; 2) "Seminal receptacle T-shaped, anterior margin of proximal part concave in the middle" but figure 187-1 (page 319) of Dang Ngoc Thanh et al. (1980) do not exhibit this feature; 3) "Apical seta on distal segment of P5 2.0 times as long as medial spine" while the illustration in figure 187-5 showed the apical seta of P5 about 1.1 times as long as 

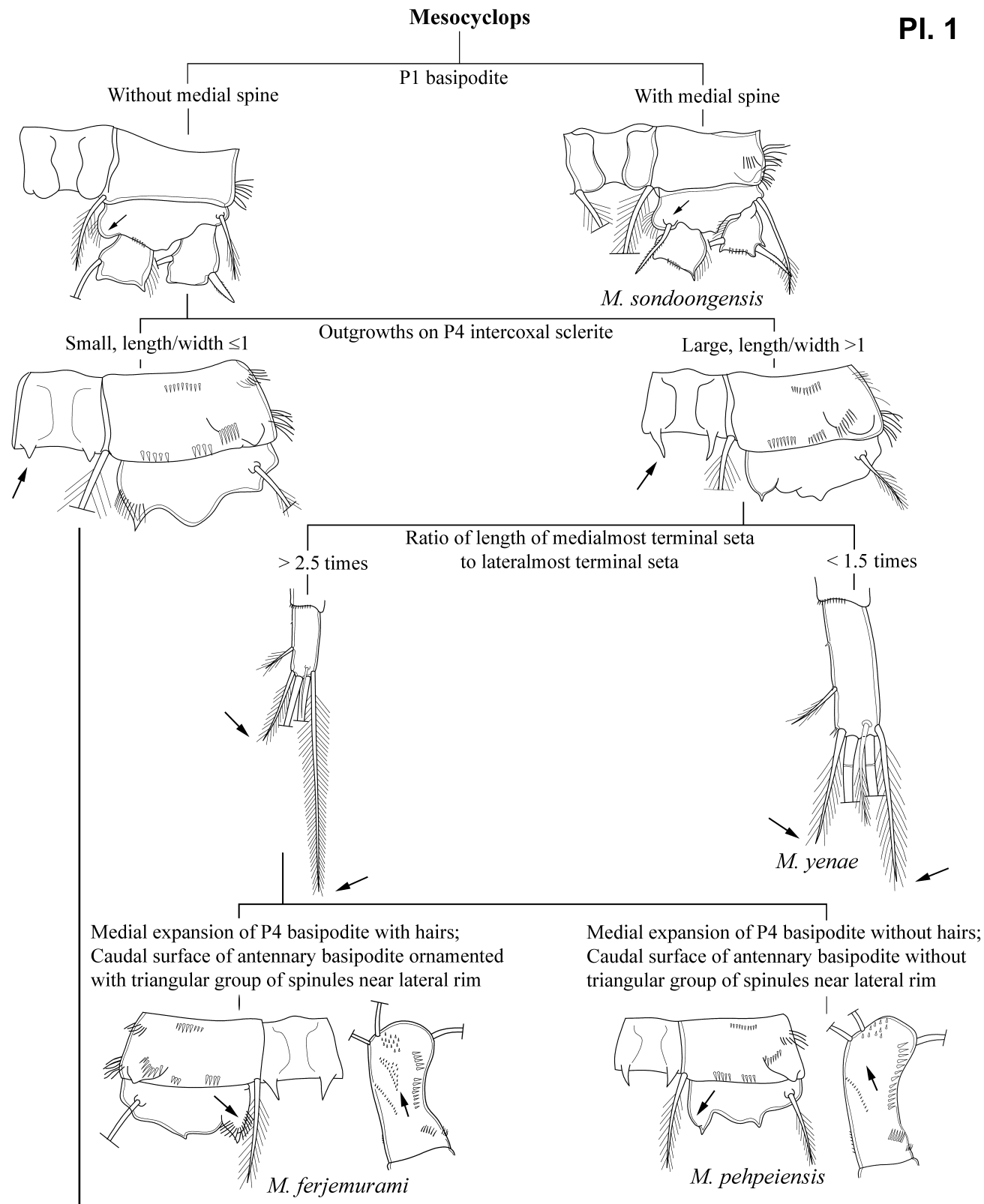

Caudal rami without medial hairs; Caudal surface of antennary basipodite without a group of spinules between proximal oblique and longitudinal spinule row

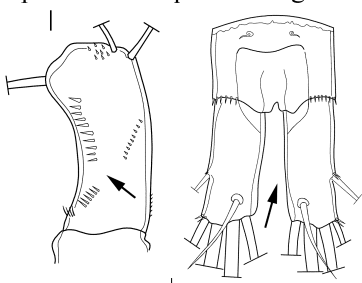

PI. 2
Caudal rami with medial hairs at whole length;

Caudal surface of antennary basipodite with a spinule group between proximal oblique and longitudinal spinule row

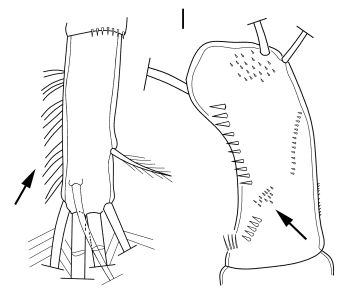

M. aspericornis 
PI.1

PI.2

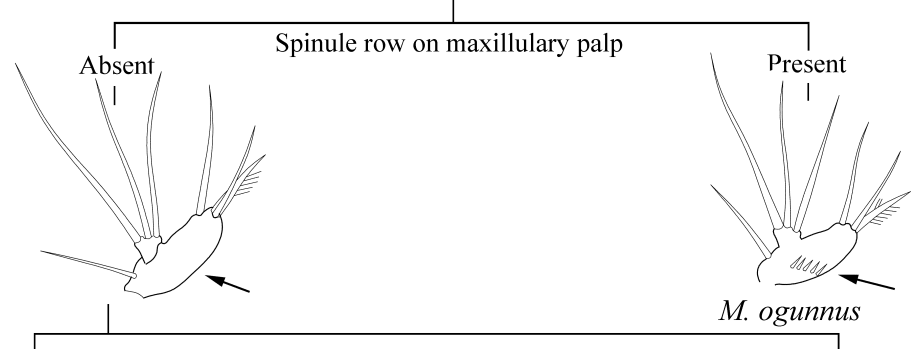

Dorsum of pediger 5 and genital double-somite without hairs; Caudal surface of antennary basipodite with group of tiny spinules near implantation of medial setae

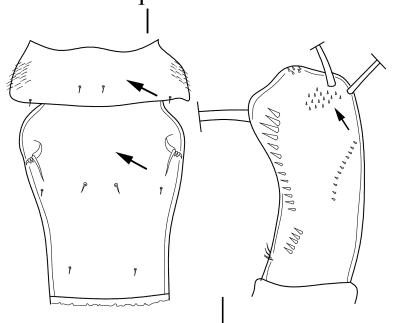

Pediger 5 and genital double-somite dorsally pilose; Caudal surface of antennary basipodite with a row of large spinules near implantation of medial setae

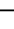

Transverse ducts meet at acute angle anterior to copulatory pore; copulatory duct strongly curved

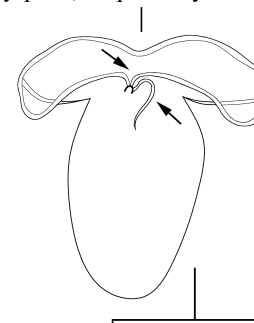

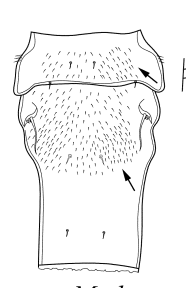

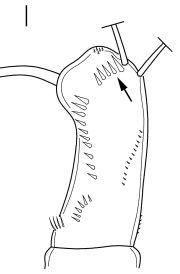

M. thermocyclopoides

Transverse ducts meet at obtuse angle anterior to copulatory pore; copulatory duct varies from straight to slightly curved

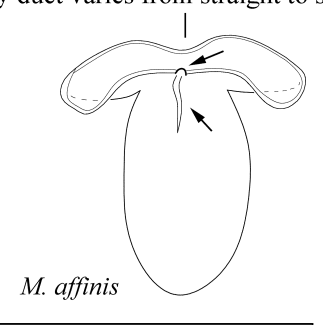

Present

Spinules at implantation of lateral caudal and lateralmost terminal setae

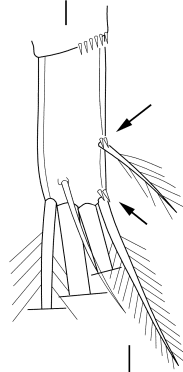

Hindgut (proctodeum) only with group of tiny spinules; Serrate hyaline membrane on last antennulary segment with two large notches

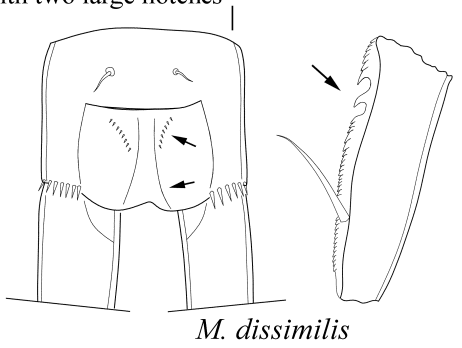

Absent

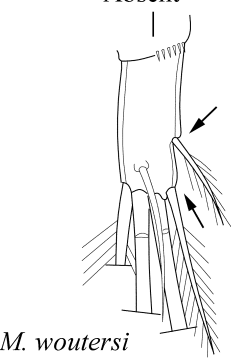

Hindgut with groups of tiny spinules and two rows of long spinules; Serrate hyaline membrane on last antennulary segment with one large notch

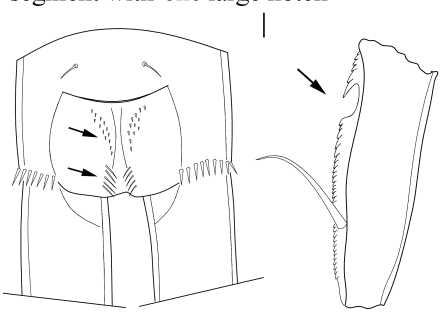

M. augusti 
The freshwater copepod genus Mesocyclops

medial spine; 4) There were no detailed descriptions or illustrations of the basopodite of antenna, copulatory pore, copulatory duct and seminal receptacle of female, which are important identifying features of this genus.

From above comparison, the identification of $M$. leuckarti collected in Vietnam might be incorrect. This could be due to the quality limitation of microscope when Dang Ngoc Thanh et al. (1980) did this work. This kind of misidentifications has also been found in Shen and Tai (1979) for Mesocyclops species in China as reported by Guo (2000). The species " $M$. leuckarti" in Vietnam is, therefore, more likely to be a different species of the genus Mesocylops, and need to have further examination to confirm its taxonomic status.

\section{Pictoral key to species of the genus Mesocyclops in Vietnam (PI.1 and Pl.2) \\ CONCLUSION}

To date, 11 copepods species of the genus Mesocyclops have been recorded in freshwater waters of Vietnam. Of these, one species is endemic to the Vietnam fauna (Mesocyclops sondoongensis Tran \& Hołyńska, 2015) and two species, Mesocyclops yenae Hołyńska, 1998, Mesocyclops feriemurami Hołyńska \& Vu, 2000) were described for the first time from Vietnam's copepod fauna.

Mesocyclops leukarti (Claus, 1857) is now removed from the list of known copepod species in Vietnam. The pictorial key to all Mesocyclops species in Vietnam are also presented and updated.

\section{REFERENCES}

Alekseev V. R., Sanoamuang L., 2006. Biodiversity of cyclopoid copepods in Thailand-with a description of Afrocyclops henrii sp. n. Arthropoda Selecta, 15(4): 277-290.

Connolly J., Watkins J. M., Hinchey E. K., Rudstam L. G., Reid J. W., 2019. The Asian cyclopoid copepod Mesocyclops pehpeiensis $\mathrm{Hu}, 1943$ reported from the western basin of Lake Erie. J. Great Lakes Res., 45(1): 196-201.

Daday E., 1906. Untersuchungen über die Copepodenfauna von Hinterindien, Sumatra und Java, nebst einem Beitrag zur Copepodenkenntnis der Hawaii-Inseln. (Reise von Dr. Walter Volz). Zoologische Jahrbücher, Abteilung für Systematik, Geographie und Biologie der Thiere, 24(3): 175-206, pls. 14-16.

Dang N. T., 1980. Khu he dong vat khong xuong song nuoc ngot Bac Viet Nam. Science and Technics Publishing House, 464 pp. (in Vietnamese).

Dang N. T., Thai T. B., Pham V. M., 1980. Dinh loai dong vat khong xuong song nuoc ngot bac Viet Nam. Science and Technics Publishing House, 573 pp (in Vietnamese).

Dang N. T., Ho T. H., Duong D. T., Mai D. Y., 2002. Thuy sinh hoc cac thuy vuc nuoc ngot noi dia Viet Nam. Science and Technics Publishing House, 399 pp (in Vietnamese).

Defaye D., Kawabata K., 1993. Mesocyclops dissimilis n. sp. from Lake Biwa, Japan (Copepoda, Cyclopoida). Hydrobiologia, 257(2): 21-126. https://doi.org/10.1007/ BF00005952

Dussart B. H., Fernando C. H., 1985. Tropical freshwater Copepoda from Papua, New Guinea, Burma, and Costa Rica, including a new species of Mesocyclops from Burma. Canadian Journal of Zoology, 63(1): 202206. https://doi.org/10.1139/z85-031

Dussart B. H., Fernando C. H., 1988. Sur quelques Mesocyclops (Crustacea, Copepoda). Hydrobiologia, 157: 241-264. https://doi.org/10.1007/BF00004201

Ghenne V., Fiers F., 2000. On Mesocyclops iranicus Lindberg, 1936 (Copepoda: Cyclopoida) and the cyclopoid collection made by Knut Lindberg during his 1935 visit to Iran. Annales Zoologici (Warszawa), 50(1): 93-98.

Guo X., 2000. A redescription of Mesocyclops 
pehpeiensis $\mathrm{Hu}, 1943$ and notes on Mesocyclops ruttneri Kiefer, 1981 (Copepoda, Cyclopidae). Hydrobiologia, 418: 33-43. https://doi.org/10.1023/ A:1004028731322

Gutiérrez-Aguirre M. A., Reid J. W., SuárezMorales E., 2003. An Afro-Asian species of Mesocyclops (Copepoda: Cyclopoida) in Central America and Mexico. Journal of Crustacean Biology, 23(2): 352-363. https://doi.org/10.1651/0278-0372(2003) 023[0352:AASOMC]2.0.CO;2

Gutiérrez-Aguirre M. A., Suárez-Morales E., Silva-Briano M., 2003. The Afro-Asian Mesocyclops aspericornis (Daday) (Copepoda, Cyclopidae) in Mexico: Comments on morphology and distribution. Crustaceana, 75(11): 1349 1361. https://doi.org/10.1163/1568540023 21629781

Gutiérrez-Aguirre M. A., Suárez-Morales E., Cervantes-Martínez A., Elías- Gutiérrez \& Previattelli D., 2006. The neotropical species of Mesocyclops (Copepoda, Cyclopoida): An upgraded identification key and comments on selected taxa. Journal of Natural History, 40: 549-570. https://doi.org/10.1080/002229306007618 37

Harada I., 1931. Studien über die süsswasserfauna formosas, IV. Susswasser-Cyclopiden aus formosa. Annotnes Zool. Jap., 13:149-168.

Hoang D. T., Phan D. D., 2011. Preliminary results from research on species composition of zooplankton in Phu Ninh Lake, Quang Nam Province. Proceeding of the $4^{\text {th }}$ National Scientific Conference on Ecology and Biological Resources, 989-995 (in Vietnamese with English summary).

Hołyńska M., 1994. A redescription of Mesocyclops thermocyclopoides Harada, 1931 (Copepoda, Cyclopidae). Bull. Inst. r. Sci. nat. Belg., Biol., 64: 99-110.

Hołyńska M., 1997. Tracing the routes of speciation in Mesocyclops woutersi- superspecies (Copepoda: Cyclopoida). Annales Zoologici (Warszawa), 47 (3/4): 321-336.

Hołyńska M., 1998. A new species of Mesocyclops (Copepoda: Cyclopoida) from Vietnam. Annales Zoologici (Warszawa), 48 (3/4): 337-347.

Hołyńska M., 2000. Revision of the Australian species of the genus Mesocyclops Sars, 2014 (Copepoda: Cyclopidae). Annales Zoologici (Warszawa), 50(3): 363-447.

Hołyńska M., 2006. Phylogeny of Mesocyclops (Copepoda: Cyclopidae) inferred from morphological character. Zoological Journal of the Linnean Society, 147(1): 1-70. https://doi.org/10.1111/ j.1096-3642.2006.00231.x

Hołyńska M., Fiers F., 1994. Mesocyclops thermocyclopoides species-group: redefinition and content. Hydrobiologia, 292/293: 41-51. https://doi.org/10.1007 /BF00229921

Hołyńska M., Vu S. N., 2000. A new Oriental species of Mesocyclops (Copepoda: Cyclopidae). Hydrobiologia, 429: 197206. https://doi.org/10.1023/A:100401863 1265

Hołyńska M., Brown M., 2003. Three New Species of Mesocyclops G. O. Sars, 1914 (Copepoda, Cyclopoida) from Australia and Burma, with comments on the Mesocyclops Fauna of Australia. Crustaceana, 75(11): 1301-1334. https://doi.org/10.1163/156854002321629 763

Hołyńska M., Reid J. W., Ueda H., 2003. Genus Mesocyclops Sars, 1914, in: Ueda H, Reid JW (Eds.), Copepoda: Cyclopoida Genera Mesocyclops and Thermocyclops. Guides to the Identification of the Microinvertebrates of the Continental Waters of the World, Volume 20, Backhuys Publishers, Amsterdam, pp. 12-214.

$\mathrm{Hu}, \mathrm{Y} . \mathrm{T} .$, 1943. Notes on fresh-water copepods from Pehpei, Szechwan. Sinensia, 14 (1-6): 115-128. 
Kawabata K., Defaye D., 1994. Description of planktonic copepods from Lake Kahokugata, Japanese Journal of Limnology, 55(2): 143-158. https://doi.org/10.3739/ rikusui.55.143

Kiefer F., 1981. Beitrag zur Kenntnis von Morphologie, Taxonomie und Geographischer Verbreitung von Mesocyclops leuckarti auctorum. Archiv für Hyrdobiologie, (Suppl.), 62(1): 148190.

Le T. N. N., Phan D. D., 2013. Diversity of zooplankton in the lower area of Long An Province. Proceeding of the $5^{\text {th }}$ National Scientific Conference on Ecology and Biological Resources, 173-178 (in Vietnamese with English summary).

Le T. N. N., Phan D. D., 2015a. Diversity of zooplankton in Dankia reservoir, Lac Duong district, Lam Dong Province. Proceeding of the $6^{\text {th }}$ National Scientific Conference on Ecology and Biological Resources, 708-713. (in Vietnamese with English summary).

Le T. N. N., Phan D. D., 2015b. Species composition and some biology index of zooplankton in Vinh Long Province. Proceeding of the $6^{\text {th }}$ National Scientific Conference on Ecology and Biological Resources, 714-721. (in Vietnamese with English summary).

Le T. N. N., Phan D. D., 2019. Zooplankton diversity in some inland freshwater bodies of Soc Trang Province. Journal of Biology, 41(2se1\&2se2): 33-44. https://doi.org/10.15625/08667160/v41n2se1\&2se2. 14146

Marten G. G., Astaiza R., Suárez M. F., Monje C., Reid J. W., 1989. Natural control of larval Anopheles albimarus (Diptera: Culicidae) by the predator Mesocyclops (Copepoda: Cyclopoida). Journal of Medical Entomology, 26(6): 624-627. https://doi.org/10.1093/jmedent/ 26.6.624
Marten G. G., Bordes E. S., Mieu N., 1994. Use of cyclopoid copepods for mosquito control. Hydrobiologia, 292/293: 491496. https://doi.org/10.1007/BF00229976

Menéndez Díaz Z., Reid J. W., Castillo Guerra I, Valdés Ramos I., 2006. A new record of Mesocyclops pehpeiensis $\mathrm{Hu}$, 1943 (Copepoda: Cyclopoida) for Cuba. Journal of Vector Ecology, 31(1): 193$195 . \quad$ https://doi.org/10.3376/10811710(2006)31[193:ANROMP]2.0.CO;2.

Mirabdullayev I. M., 1996. The genus Mesocyclops (Crustacea: Copepoda) in Uzbekistan (Central Asia). Internationale Revue der gesamten Hydrobiologie und Hydrographie, 81(1): 93-100. https://doi.org/10.1002/iroh.19960810111

Mirabdullayev I. M., Stuge T. S., Kuzmetov A. R., 1995. On Mesocyclops ruttneri Kiefer, 1981 a species new to Kazakhstan. Selevinia, 2: 31-33.

Onabamiro S. D., 1957. Some new species of Cyclops sensu lat. (Crustacea: Copepoda) from Nigeria. Journal of the Linnean Society, Zoology, 43: 123-133. https://doi.org/10.1111/j.1096-3642.1957. tb02514.x

Phan D. D., Nguyen V. K., Le T. N. N., Dang N. T., Ho T. H., 2015. Identification Handbook of Freshwater Zooplankton of the Mekong River and its Tributaries, Mekong River Commission, Vientiane, $207 \mathrm{pp}$.

Reid J. W., 1993. New records and redescriptions of American species of Mesocyclops and of Diacyclops bernardi (Petkovsky, 1986) (Copepoda, Cyclopoida). Bijdragen tot de Dierkunde, 63(3): 173-191. https://doi.org/10.1163/ 26660644-06303004

Reid J. W. and B. H. Kay. 1992. Mesocyclops guangxiensis, new species, and new records of four congeners (Crustacea: Copepoda: Cyclopidae) from China, Laos, and Viet Nam. Proceedings of the 
Biological Society of Washington, 105(2): 331-342.

Rylov V. M., 1948. Cyclopoida Presnykh Vod. Fauna SSSR, Rakoobraznye, Zoological Institute, Academy of Sciences of the U.S.S.R., Leningrad, $314 \mathrm{pp}$.

Suárez-Morales E, Gutiérrez-Aguirre M. A., Torres J. L., Hernández F., 2005. The Asian Mesocyclops pehpeiensis Hu, 1943 (Crustacea, Copepoda, Cyclopidae) in Southeast Mexico with comments on the distribution of the species. Zoosystema, 27: 245-256. https://doi.org/10.1016 /j.jglr.2018.11.005

Tran D. L, Hołyńska M., 2015. A new Mesocyclops with archaic morphology from a karstic cave in Central Vietnam, and its implications for the basal relationships within the genus. Annales zoologici (Warszawa), 65(4): 661-686.

Ueda H., Ishida T., 1997. Species composition and description of limnoplanktonic copepods from Okinawa. Plankton Biology and Ecology, 44(1/2): 41-54.

Ueda H., Ishida T., Imai J., 1997. Planktonic cyclopoid copepods from small ponds in Kyushu, Japan. II. Subfamily Cyclopinae. Hydrobiologia, 356: 61-71. https://doi.org/10.1023/A:1003155710590

Van de Velde I., 1984. Revision of the African species of the genus Mesocyclops Sars, 1914 (Copepoda: Cyclopidae).
Hydrobiologia, 109: 3-66. https://doi.org/ 10.1007/BF00006297

Van de Velde I., 1987. New Mesocyclops species (Copepoda, Cyclopidae) from Papua New Guinea. Bulletin de l'Institut Royal des Sciences Naturelles de Belgique, Biologie, 57: 149-162.

Vo V. P. \& Hoang D. T., 2012. Study of fluctuation of zooplankton in Tam GiangCau Hai lagoon system, Thua Thien Hue Province. Hue University Journal of Science: Natural Science, 75(6): 123-133 (in Vietnamese with English summary).

Vu S. N., Nguyen T. Y., Kay B. H., Reid J. W., 1998. Eradication of Aedes aedypti from a village in Vietnam, using copepods and community participation. The American Journal of Tropical Medicine and Hygiene, 59(4): 657-660. https://doi.org/10.4269/ajtmh.1998.59.657

Vu S. N., Nguyen T. Y., Hołyńska M., Reid J.W., Kay B., 2000. National progress in dengue vector control in vietnam: survey for Mesocyclops (Copepoda), Micronecta (Corixidae), and fish as Biological control agents. The American Journal of Tropical Medicine and Hygiene, 62(1): 5-10. https://doi.org/10.4269/ajtmh.2000.62.5

Vu S. N., Kay B., Nguyen T. Y., Ryan P., Bektas A., 2004. Community mobilization, behaviour change and biological control in the prevention and control of dengue fever in Vietnam. Dengue Bulletin, 28: 57-61. 